\title{
Knowledge, Attitude and Practice of Diabetes Control among Patients, Khartoum Teaching Hospital
}

\author{
Hassan Isse Ahmed ${ }^{1}$, Nur Mohamed Egal ${ }^{2}$, Shadia Mohamed $^{3}$ \\ ${ }^{1,2,3}$ University of Bahri, College of Public and Environment
}

\begin{abstract}
Purpose: The problem of diabetic care in Sudan includes poor awareness and compliance with therapy or diet, lack of efficient Diabetic care centers, lack of specially trained personnel, the purpose of the study to identify the Knowledge and Attitude of diabetes control among patients at Khartoum teaching hospital. Objective: To identify the awareness of diabetics about complications that may occur with diabetes and how can they deal with this complication, to assess and evaluate advice given to the diabetic patients in compliance with the follow up and health care services given to them by the Diabetics Care Units at the hospital. Material and Method: 50 Diabetic patients were interviewed to collect information to identify diabetic patient's awareness. Data was collected by researchers using questionnaire. Results: $50 \%$ of the patient's examined with age ranged between $41-50 y e a r$. (60\%) of the patients had the diabetes since 5years. (72\%) didn't have a glucometer, (38\%) of diabetic patient missed their doses more than twice. The glucose level of (46\%) patients were 180-250mg/dl, (54\%) of patients were admitted to hospital due to diabetic complication. Some of the patients had days off work due to diabetes. There was positive correlation between level of education and clinical discovery of diabetes, follow up with dietician and feet examination. Conclusion:- Most of the patients had poor follow up with their doctors; they didn't know the importance of diabetic education, taking treatment in accurate time and eye, feet checking.
\end{abstract}

Keywords: Health, Education, Diabetes care, Awareness, Sudan

\section{Introduction}

Diabetes mellitus is a group of diseases characterized by High blood glucose concen-trations resulting from defects in Insulin secretion, insulin action, or both. Abnormalities in the metabolism of carbohydrate, protein, and fat are also present. Persons with diabetes have bodies that do not produce or respond to insulin, a hormone produced by the Bcells of the pancreas that is necessary for the use or storage of body fuels. Without effective insulin, hyperglycemia (Elevated blood glucose) occurs, which can lead to serious

Complications and premature death; but, people with diabetes can take steps to control the disease and lower the risk of complications. (1). Diabetes mellitus is also defined as a condition characterized by an elevation of the level of glucose in the blood. Insulin, a hormone produced by the pancreas, controls the blood glucose level by regulating the production and storage of glucose (2).

\subsection{Types of diabetes}

There are four major classifications of diabetes mellitus, namely:-

1.1.1-Type I diabetes is known as insulin dependent diabetes mellitus" IDDM" .About $5-10 \%$ of patient have type I diabetes mellitus. The pancreas produces inadequate amounts of insulin, resulting in the need for insulin therapy to control the blood glucose. It is characterized by a sudden onset, usually before the age of 30 years.

1.1.2-Type II is none insulin dependent diabetes mellitus "NIDDM". It results from a decrease in the sensitivity of the cells to insulin and a decrease in the amount of insulin produced. About $90-95 \%$ of patients have type II diabetes.
1.1.3-Type III This is where diabetes mellitus is associated with other conditions, for example, pancreatic disease, hormonal disorders and drugs such as gluco-corticoids and estrogen-containing preparations. Depending on the ability of the pancreas to produce insulin, the patient may require oral agents or insulin (3).

1.1.4-Gestational diabetes mellitus:- The onset of Gestational diabetes mellitus is during pregnancy, usually in the second or third trimester, as a result of hormones secreted by the placenta, which inhibit the action of insulin. It occurs in about $2-5 \%$ of pregnancies. About $30-40 \%$ of patients with gestational diabetes mellitus will develop type II diabetes within 5-10 years (especially if obese). Impaired glucose tolerance and statistical risk groups are examples of gestational diabetes mellitus. (2) (3).

\subsection{Clinical Management of Diabetes}

Clients should eat three meals per day, with snack in the late afternoon and before bed time in order to coincide with peak action times of insulin. The diet should be will balanced; calorie controlled, and avoids concentrated sweets (4).

1.2.1-A low-fat diet is recommended to reduce the risk of elevated serum cholesterol levels, and reduce weight. Vegetables can be eaten raw or boiled (without the addition of sugar, salt or butter). Spices, herbs and salted meant for hypertensive patients, that are available at selected supermarkets, should be used instead of ordinary salt. These reduce the accumulation of fluids in the body caused by the intake of ordinary salt. Snacks should be part of the diet and should be taken between meals to prevent hypoglycemia and to prevent the patient from eating full meals frequently which can lead to weight gain (5). 


\section{International Journal of Science and Research (IJSR) \\ ISSN (Online): 2319-7064 \\ Index Copernicus Value (2013): 6.14 | Impact Factor (2014): 5.611}

1.2.2-Exercise is considered an essential part of diabetic management. It contributes to the reduction of weight and cholesterol level. Exercise is important because of its effect on lowering blood glucose and reducing cardiovascular risk factors. It increases the uptake of glucose by the body muscles and improves insulin utilization. Patients should be encouraged to exercise daily at the same time and for the same amount to maintain constant, normal blood glucose levels. Patients need to consult the health care personnel before resuming with exercise to give them advice on when to exercise and when not. This is important because exercising with elevated blood glucose levels will cause increased secretion of glucagons, growth hormone and catecholamine. The liver will then release more glucose, resulting in an increase in blood glucose. Exercise should therefore not be performed until blood glucose levels are under $14 \mathrm{mmol} / \mathrm{L}$. Patients should monitor blood glucose levels before, during and after exercise to determine the effect exercise has on the blood glucose level at particular times of the day.

Exercise can be in the form of walking, swimming, aerobics, playing soccer or participating in athletics (6) (7).

\subsection{Control of Diabetes}

Diabetes as a self-managed condition requires from patients relevant knowledge, skills and attitudes for the successful management of diabetes.

Counseling and health education should include information on regular home monitoring of blood and urine glucose levels, weight control, dietary restrictions, regular exercise, foot care eye care. They must be reassured about the continuity of care and the value of compliance with the treatment regimen, and the family should be involved in the treatment regimen to offer support and encouragement. (8)

\section{Results and Discussion}

Table 1: General Characteristics.

\begin{tabular}{|c|c|c|}
\hline Age & Frequency & Percent $) \%($ \\
\hline$<30$ yrs & 4 & 8.0 \\
\hline $30-40$ yrs & 10 & 20.0 \\
\hline $41-50$ yrs & 25 & 50.0 \\
\hline $51-60$ yrs & 11 & 22.0 \\
\hline Total & 50 & 100.0 \\
\hline Gender & & \\
\hline Male & 30 & 60.0 \\
\hline Female & 20 & 40.0 \\
\hline Total & 50 & 100.0 \\
\hline Marital Status & & \\
\hline Single & 18 & 36.0 \\
\hline Married & 32 & 64.0 \\
\hline Total & 50 & 100.0 \\
\hline Occupation & & \\
\hline Employed & 30 & 60.0 \\
\hline Unemployed & 20 & 40.0 \\
\hline Total & 50 & 100.0 \\
\hline
\end{tabular}

Table No 1. Show the characteristics of the respondents. The majority their age ranged $41-50$ year, $60 \%$ were males, $64 \%$ of them were married and $60 \%$ were working in permanent jobs.
Table 2: Absent from work

\begin{tabular}{|c|c|c|}
\hline Absentee last month & Frequency & )\%( \\
\hline$<10$ days & 17 & 56.67 \\
\hline 10-20days & 8 & 26.67 \\
\hline 20-30days & 4 & 13.33 \\
\hline$>1$ month & 1 & 3.33 \\
\hline Total & 30 & 100 \\
\hline
\end{tabular}

Table No 2. Shows the absent of the study group from their work due to illness. $56.6 \%$ of the patients had days off work due to some illness in the last month. The study reveal that most absence due to diabetes illness.

Table 3: Duration of diabetes mellitus

\begin{tabular}{|c|c|c|}
\hline Duration of diabetes mellitus & Frequency & Percent $) \%($ \\
\hline$<5$ yrs & 30 & 60.0 \\
\hline $5-10 \mathrm{yrs}$ & 12 & 24.0 \\
\hline$>10 \mathrm{yrs}$ & 8 & 16.0 \\
\hline Total & 50 & 100.0 \\
\hline
\end{tabular}

Table No 3. Shows the time since the study group member discover they are diabetic case. $60 \%$ got the disease in a period less than 5 years

Table 4: Treatment

\begin{tabular}{|c|c|c|}
\hline Type of treatment & Frequency & )\%( \\
\hline Dietary control & 5 & 10.0 \\
\hline Hypoglycemic drugs & 12 & 24.0 \\
\hline Insulin & 32 & 64.0 \\
\hline Regular physical exercise & 1 & 2.0 \\
\hline Total & $\mathbf{5 0}$ & $\mathbf{1 0 0 . 0}$ \\
\hline
\end{tabular}

Table NO4 represents the treatment used by the study group to control blood glucose. $64 \%$ controlled their diabetes by insulin. There is few group used physical exercise $2 \%$, these group should consult a specialist to advice them about the suitable treatment to control blood glucose. Nutrition education is very important to this group.

Table 5: Monitoring Diabetes

\begin{tabular}{|c|c|c|}
\hline Monitoring Diabetes & Frequency & $\mathbf{) \% (}$ \\
\hline Weekly & 20 & 40.0 \\
\hline Every 2 weeks & 9 & 18.0 \\
\hline Monthly & 17 & 34.0 \\
\hline Every 3 months & 2 & 4.0 \\
\hline Not follow & 2 & 4.0 \\
\hline Total & 50 & 100.0 \\
\hline
\end{tabular}

Table NO5. Shows the specific time set by the respondents to monitor their condition due to the diabetes. The majority of diabetic patient monitor their diabetic in specific time but only small group $4 \%$ are not follow their diabetic condition. These small group needs nutrition education about the important of follow up to avoid complication due to uncontrolled of glucose level.

Table 6: Special Diabetic Diet

\begin{tabular}{|c|c|c|}
\hline $\begin{array}{c}\text { Special diabetic food in the } \\
\text { last 3 months }\end{array}$ & Frequency & )\%( \\
\hline Yes & 13 & 26.0 \\
\hline No & 37 & 74.0 \\
\hline Total & $\mathbf{5 0}$ & $\mathbf{1 0 0 . 0}$ \\
\hline
\end{tabular}




\section{International Journal of Science and Research (IJSR) \\ ISSN (Online): 2319-7064 \\ Index Copernicus Value (2013): 6.14 | Impact Factor (2014): 5.611}

Table No 6. Represent the used of diet that the diabetic patient to follow. The study reveals that $74 \%$ of respondents do not know the diet which used in case diabetes to control the blood glucose level. Diabetic patient should be aware about the suitable food and know how to control their blood glucose to avoid the diabetes complications.

Table 7: Miss the Dose

\begin{tabular}{|c|c|c|}
\hline miss dose & Frequency & )\%( \\
\hline Once & 6 & 12.0 \\
\hline Twice & 15 & 30.0 \\
\hline More than two & 19 & 38.0 \\
\hline Never & 10 & 20.0 \\
\hline Total & 50 & 100.0 \\
\hline
\end{tabular}

Table NO.7.Shows the frequency of missing of the respondents the medical dose used in the treatment of diabetes. Most of the study group miss their dose between once to more than two. Only $10 \%$ never miss their dose used for treatment of diabetes.

Table 8: Examine Feet

\begin{tabular}{|c|c|c|}
\hline Ever examine feet & Frequency & )\%( \\
\hline Yes & 18 & 36.0 \\
\hline No & 32 & 64.0 \\
\hline Total & 50 & 100.0 \\
\hline
\end{tabular}

Table No 8. Shows that during the last year, has doctor or other health professional ever examined the feet of the diabetic patient. $64 \%$ of the respondent $\mathrm{s}$ are not aware about the important of feet check. Beside from the result of this study the most of them miss their dose of drug, not know the suitable diet.

Table 9: Eyes Examination

\begin{tabular}{|c|c|c|}
\hline Eyes examination & Frequency & )\%( \\
\hline Yes & 23 & 46.0 \\
\hline No & 27 & 54.0 \\
\hline Total & 50 & 100.0 \\
\hline Eye problem & & \\
\hline Yes & 38 & 76.0 \\
\hline No & 12 & 24.0 \\
\hline Total & 50 & 100.0 \\
\hline
\end{tabular}

Table No 9. Shows the eye examines done by the respondents, and the problem affect $\mathrm{s}$ the eye due to diabetes. $54 \%$ of the respondent are not examined their eyes since they discovered the diabetes, and $76 \%$ of them have eye problem.

Table 10: Diabetes Health Education

\begin{tabular}{|c|c|c|}
\hline Diabetes educator & Frequency & )\%( \\
\hline Yes & 13 & 26.0 \\
\hline No & 37 & 74.0 \\
\hline Total & 50 & 100.0 \\
\hline
\end{tabular}

Table No10. Shows the real health education which diabetic patient attends. $74 \%$ of the respondents are not attends any diabetes health education. These leads to most of them mist the drug dose, not know the suitable diet, not used special diabetic diet, and have eye problem.
Table 11: Dietitian consultation

\begin{tabular}{|c|c|c|}
\hline Consultation & Frequency & $\mathbf{) \% (}$ \\
\hline Yes & 17 & 34.0 \\
\hline No & 33 & 66.0 \\
\hline Total & 50 & 100.0 \\
\hline
\end{tabular}

Table No 11. Represents consulting of the study group a dietitian. $66 \%$ of the respondents are not consulting a dietitian to get knowledge about suitable diet for the diabetic patient. These may be the reason for high blood glucose level when the study group examine during the interview.

Table 12: Blood glucose level

\begin{tabular}{|c|c|c|}
\hline Blood glucose level & Frequency & Percent )\%( \\
\hline $100-180$ & 6 & 12.0 \\
\hline $180-250$ & 23 & 46.0 \\
\hline More than $250 \mathrm{mg} / \mathrm{dl}$. & 21 & 42.0 \\
\hline Total & 50 & 100.0 \\
\hline
\end{tabular}

Table NO12. Shows level of blood glucose. $46 \%$ of the respondents their blood glucose level was $180-250 \mathrm{mg} / \mathrm{dl}$ and $42 \%$ their blood glucose more than $250 \mathrm{mg} / \mathrm{dl}$ when the study group examine during the interview. These results reveal that most of the study group has high blood glucose level.

Table 13: Admitted to hospital

\begin{tabular}{|c|c|c|}
\hline Admitted & Frequency & )\%( \\
\hline Yes & 27 & 54.0 \\
\hline No & 23 & 46.0 \\
\hline Total & 50 & 100.0 \\
\hline
\end{tabular}

Table No 13. Shows admitted of the study group to a hospital in the previous year. $54 \%$ of patients were admitted to the hospital due to diabetic complications.

Table 14: Following instructions

\begin{tabular}{|c|c|c|}
\hline Following instructions & Frequency & Percent $) \%($ \\
\hline Yes & 2 & 4.0 \\
\hline No & 48 & 96.0 \\
\hline Total & 50 & 100.0 \\
\hline
\end{tabular}

Table NO14 Shows follow up of the study group to the instructions given them by the doctors. $96 \%$ of the patients were not follow doctor instructions in taking drugs. This result explains the high number of diabetic patient admitted to the hospital.

\section{Conclusion}

Most of the patients had poor follow up with their doctors; they didn't know the importance of diabetic education, taking treatment in accurate time and eye, feet checking.

\section{Recommendation}

The researchers recommended that the media should take part in encouragement of diabetic patients to visit health educators and nutritionists to know more about diabetes mellitus. 


\section{References}

[1] Krause and Mahan; (2008): Krause's food and nutrition therapy. International Edition, 12e. ISBN: 978-0-80892378-7.

[2] Smeltzer, SG \& Bare, BG; (1996): Brunner and Suddath's textbook of medical-surgical nursing. 1996. $9^{\text {th }}$. ed, JB Lippincott, Philadelphia, Pp. 022-1063.

[3] Royle, J., A. \& Walsh M. (1992): Watson's MedicalSurgical Nursing and Related Physiology, 1992. $4^{\text {th }}$. ed, Baillère Tindall, London. ISBN: 0-7020-1515-6. pp 596597

[4] Friderichsen B, Maunsbach M.; (1997): Glycosuric Tests should not be employed in Population Screenings for NIDDM, J Public Health Med. 19(1). p58.

[5] Mohamed Inam; Danish,MD; (2009): Medical diagnosis and management, $11^{\text {th }}$ edition, paramount publishing interprice, Karachi Pakistan,

[6] Helen Harkteader and Mary Ann Hogan; (2004): Fundamental of Nursing, Sander, $2^{\text {nd }}$ ed, $p$ (546-730).

[7] Peter, H; (2007): Understanding diabetes. $11^{\text {th }}$ Edition. MD; ISBN 978- 09673987.

[8] Richardson A, Adner N, Nordstrom G, 2001. Persons with Insulin Dependent Diabetes Mellitus: Acceptance and Coping Ability ${ }^{\text {th }}$ ed. JB Lippincott, Philadelphia, $p$ 759 .

\section{Author Profile}

Hassan Isse Ahmed. University of Bahri-Sudan.

Nur Mohamed Egal. University of Bahri-Sudan

Shadia Mohamed Idriss Bakheit received the B.Sc., M.Sc., PhD, and degree in Home Science / Nutrition from Ahfad University for women, university of Khartoum-Sudan, 1989, 1997, and 2000, respectively. She worked at Khartoum Teaching Hospital Sudan 1990-1997, University of Juba, College of Community Studies \& Rural Development 1997-2011, University of Bahri-Sudan 2011. University of Hail / KSA, 2011-2014. She worked now, as Associate professor at University of Bahri-Sudan. 